\title{
Arctiinae moths (Lepidoptera, Erebidae) of the Emas National Park, Goiás, Brazil
}

\author{
Carolina Moreno $^{1,3}$ \& Viviane G Ferro ${ }^{2}$ \\ ${ }^{1}$ Universidade Federal de Goiás, Caixa Postal 131, Programa de Pós-Graduação em Ecologia e Evolução, \\ Campus II, Samambaia, km 13, 74001-970, Goiânia, GO, Brazil. \\ ${ }^{2}$ Universidade Federal de Goiás, Departamento de Ecologia, Instituto de Ciências Biológicas, \\ Goiânia, GO, Brazil. \\ ${ }^{3}$ Corresponding author: Carolina Moreno,e-mail: s.moreno.carol@gmail.com
}

MORENO, C., FERro, V.G. Arctiinae moths (Lepidoptera, Erebidae) of the Emas National Park, Goiás, Brazil. Biota Neotropica. 16(2): e20150037. http://dx.doi.org/10.1590/1676-0611-BN-2015-0037

\begin{abstract}
Arctiinae are a species-rich subfamily of moth, with approximately 1,400 species in Brazil and 723 recorded in the Cerrado biome. A list of species of these moths was compiled during three years of sampling in four vegetation types within the Emas National Park. A total of 5,644 individuals belonging to 149 species were collected. About $67 \%$ of these species are new records for the Emas National Park, $31 \%$ for the State of Goiás and $9 \%$ for the Cerrado biome. Cerrado sensu stricto and semideciduous forests have higher species richness, followed by campo cerrado and campo sujo. The vegetation type with the highest number of exclusive species was the semideciduous forest, followed by cerrado sensu stricto, campo cerrado and campo sujo. The high species richness and the high proportion of new species records for Goiás and Cerrado reinforce the importance of the Emas National Park region as a center of diversity for this group of moths. The conservation of areas not yet cleared around the Park, including the creation of new protected areas, and the establishment of ecological corridors between these areas and the Park would be strategies to preserve the fauna of these moths.
\end{abstract}

Keywords: light trap, Lithosiini, Arctiini.

MORENO, C., FERRO, V.G. Mariposas Arctiinae (Lepidoptera, Erebidae) do Parque Nacional das Emas, Goiás, Brasil. Biota Neotropica. 16(2): e20150037. http://dx.doi.org/10.1590/1676-0611-BN-2015-0037

Resumo: Arctiinae é uma das subfamílias de mariposas mais ricas em espécies. Já foram registradas cerca de 1400 espécies no Brasil e 723 no bioma Cerrado. Uma lista de espécies destas mariposas foi compilada de três anos de amostragens realizadas em quatro fitofisionomias do Parque Nacional das Emas. Um total de 5.644 indivíduos, pertencentes a 149 espécies foram coletados. Cerca de $67 \%$ das espécies representam novos registros para o Parque Nacional das Emas, 31\% para o Estado de Goiás e 9\% para o bioma Cerrado. Cerrado sensu stricto e mata estacional semidecídua apresentaram maior riqueza de espécies, seguidas por campo cerrado e campo sujo. A fitofisionomia que apresentou maior número de espécies exclusivas foi a mata estacional semidecídua, seguida por cerrado sensu stricto, campo cerrado e campo sujo. A grande riqueza de espécies e a alta proporção de novos registros de espécies para Goiás e para o Cerrado reforçam a importância da região do Parque Nacional das Emas como um centro de diversidade para esse grupo de mariposas. A conservação das áreas ainda não desmatadas no entorno do Parque, incluindo a criação de novas unidades de conservação, e o estabelecimento de corredores ecológicos entre essas áreas e o Parque seriam estratégias para preservar a fauna dessas mariposas.

Palavras-chave: armadilha luminosa, Lithosiini, Arctiini.

\section{Introduction}

The biodiversity knowledge is still insuficient due the Linnean and Wallacean shortfalls (Bini et al., 2006). The first is related to the lack of taxonomists, since a significant proportion of species have not been described for many taxa, mainly the rich tropical invertebrate groups. The second is related to the limited knowledge of species occurrences, since, for the majority of taxa, geographical distributions are poorly understood and contain many gaps. The best way to reduce the
Wallacean shortfall is to invest in biodiversity inventories and publish lists of species. The results of these inventories, i.e. the species lists, provide support for actions on conservation and management, which are especially important in areas undergoing rapid environmental degradation (Lewinsohn et al. 2005). They are also important in macroecological and evolutionary studies.

Arctiinae moths are a species-rich subfamily of Lepidoptera (Heppner 1991). There are approximately 11,000 species worldwide, with 6,000 in the Neotropics (Watson \& Goodger 1986) 
and 1,400 in Brazil (Ferro \& Diniz 2010). According to Ferro et al. (2010), 723 Arctiinae species have been recorded in the Brazilian Cerrado. However, the number of species occurring in this biome should be much higher, because less than $60 \%$ of the one degree latitude/longitude cells that cover the area of the Cerrado have sampling records of Arctiinae, and only one of these cells was adequately sampled (Ferro et al. 2010).

According to the new classification of Zahiri et al. (2012), Arctiinae moths consist of the tribes Arctiini, Lithosiini, Amerilini and Syntomini, with the two latter not occurring in the Neotropics (Heppner 1991, Hauser \& Boppré 1997). The vast majority of Lithosiini species have a small body size (Weller et al. 2009). The moths of this tribe mainly feed on mosses, lichens and algae (Weller et al. 2009) and are generally more associated with vegetation types in early stages of succession (Hilt \& Fiedler 2006). The Arctiini tribe are composed of small to medium sized moths whose larvae feed on a wide variety of plants, including grasses, herbs, shrubs and trees (Weller et al. 2009). Furthermore, Arctiini moths can explore different vegetation types because they are polyphagous (Singer \& Bernays 2009) and can therefore inhabit a wide variety of terrestrial habitats.

The Cerrado is a biodiversity hotspot for conservation priorities (Myers et al. 2000). Only 2\% of its area is legally protected (Klink \& Machado 2005) and the Arctiinae fauna is not known properly, even in this area. The Cerrado biome is composed by a wide variety of vegetation types ranging from open areas with no shrub element to areas with a high density of tall trees (Oliveira-Filho \& Ratter 2002). The vegetation types that comprise the cerrado sensu lato are campo limpo, campo sujo, campo cerrado, cerrado sensu stricto and cerradão. These five vegetation types represent a gradient of vegetation increasing in woody plant density and decreasing in herbaceous density (Oliveira-Filho \& Ratter 2002). The Cerrado also contains forest formations, which are not considered to belong to the cerrado sensu lato (Oliveira-Filho \& Ratter 2002). The Arctiinae moths respond to these differences in vegetation, and the fauna of the forest formations differs from the savanna formations (Ferro \& Diniz 2007, Moreno et al. 2014).

We present a list of Arctiinae moth species of the Emas National Park, one of the largest conservation units of the Cerrado biome. The park includes the Brazilian Long Term Ecological Research Network. We have performed sampling in different vegetation types of the park and measured the observed and extrapolated richness of species across the study area and in each vegetation type. We have also measured the exclusive species of each vegetation type and the number of species that are new records for the Park, the State of Goiás and for the Cerrado biome.

\section{Material and Methods}

Specimens of Arctiinae were sampled in the Emas National Park (ENP), located between the cities of Mineiros and Chapadão do Céu, in the State of Goiás, Central West of Brazil $\left(17^{\circ} 49^{\prime}-18^{\circ} 28^{\prime} \mathrm{S}\right.$ and $\left.52^{\circ} 39^{\prime}-53^{\circ} 10^{\prime} \mathrm{W}\right)$ (Figure 1). The ENP covers 132,941 ha and approximately $80 \%$ of this area consists of grasslands (campos limpos and campos sujos). Approximately $15 \%$ of the ENP area is composed of campo cerrado and cerrado sensu stricto and $5 \%$ of the remaining area consists of campos úmidos, veredas and forests (França et al.
2007). The climate is Aw in Koppen classification, i.e. the climate is tropical humid with three to six months of dry winter and rainy summer, which imposes a strong seasonality in the vegetation (Ramos-Neto \& Pivello 2000). The annual precipitation ranges from 1,200 to $2,000 \mathrm{~mm}$, concentrated between September and March, with an average annual temperature of $24.6^{\circ} \mathrm{C}$ (Ramos-Neto \& Pivello 2000).

Sampling units consisted of 40 plots of $10 \times 10 \mathrm{~m}$, distributed in four vegetation types: semideciduous forest ( $\mathrm{n}=10$ plots); cerrado sensu stricto $(\mathrm{n}=10$ plots); campo cerrado $(\mathrm{n}=14$ plots); campo sujo $(\mathrm{n}=$ six plots) (Figure 1$)$. In each plot, the moths were collected from dusk until dawn through a Luiz de Queiroz light trap (Silveira-Neto \& Silveira 1969) equipped with a $15 \mathrm{~W}$ black lamp. The traps were suspended $1.5 \mathrm{~m}$ above the ground in the center of each plot. The minimum distance between plots was $100 \mathrm{~m}$ to minimize the capture of species from surrounding vegetation types. This distance corresponds to the radius of attraction of a $125 \mathrm{~W}$ lamp (MuirheadThompson 1991), a power eight times greater than that we used in this study. Sampling was restricted to periods of new and waning lunar phases due to the radius of attraction of the traps being greater (Yela \& Holyoak 1997). Sampling was conducted for three years during both the dry (June to July 2010, July 2011 and July 2012) and rainy seasons (December 2010 to February 2011, November 2011 and December 2012). The moths were collected in all plots over two non-consecutive nights in order to increase the representativeness of the fauna, totaling 12 nights of sampling in each plot ( 2 in each dry season and 2 in each rainy season) and 84 nights of sampling in total. On each sampling night, we set eight light traps, two in each vegetation type. Plots sampled in the same night were the most distant possible to avoid pseudoreplication. Each plot was sampled once at the new moon and once during the waning moon.

Arctiinae individuals were identified by comparison with digital images of the identified species of the V.O. Becker Collection (where the identification was confirmed by comparison with types) and through the literature (Hampson, 1898, 1900, 1901, 1914, Watson \& Goodger 1986, Piñas-Rubio et al. 2000, Piñas-Rubio \& Manzano 2003). All individuals were deposited in the Zoological Collection of the Federal University of Goiás (Goiânia, Brazil).

We used three non-parametric species richness estimators (first and second order Jackknife and second order Chao) to better estimate the total richness of Arctiinae in the study area and in each vegetation type. These three estimators are based on incidence (presence/ausence) of species in assemblages (Melo 2004).

\section{Results}

We recorded 5,644 Arctiinae individuals during our sampling; belonging to 149 species, 73 genera, two tribes (Arctiini and Lithosiini) and nine subtribes (Arctiina, Callimorphina, Cisthenina, Ctenuchina, Euchromiina, Eudesmiina, Lithosiina, Pericopina and Phaegopterina). Of the 149 species sampled, 117 were identified to the species level $(78 \%), 16$ at the genus level $(10 \%)$ and 16 at the tribal level (10\%) (Appendix 1). The subtribe with the highest number of species was Phaegopterina (46 species, $30 \%$ of the total), followed by Euchromiina (30, 20\%), Ctenuchina (26, 17\%), Cisthenina (13, 8\%), Lithosina (7, 4\%), Arctiina 


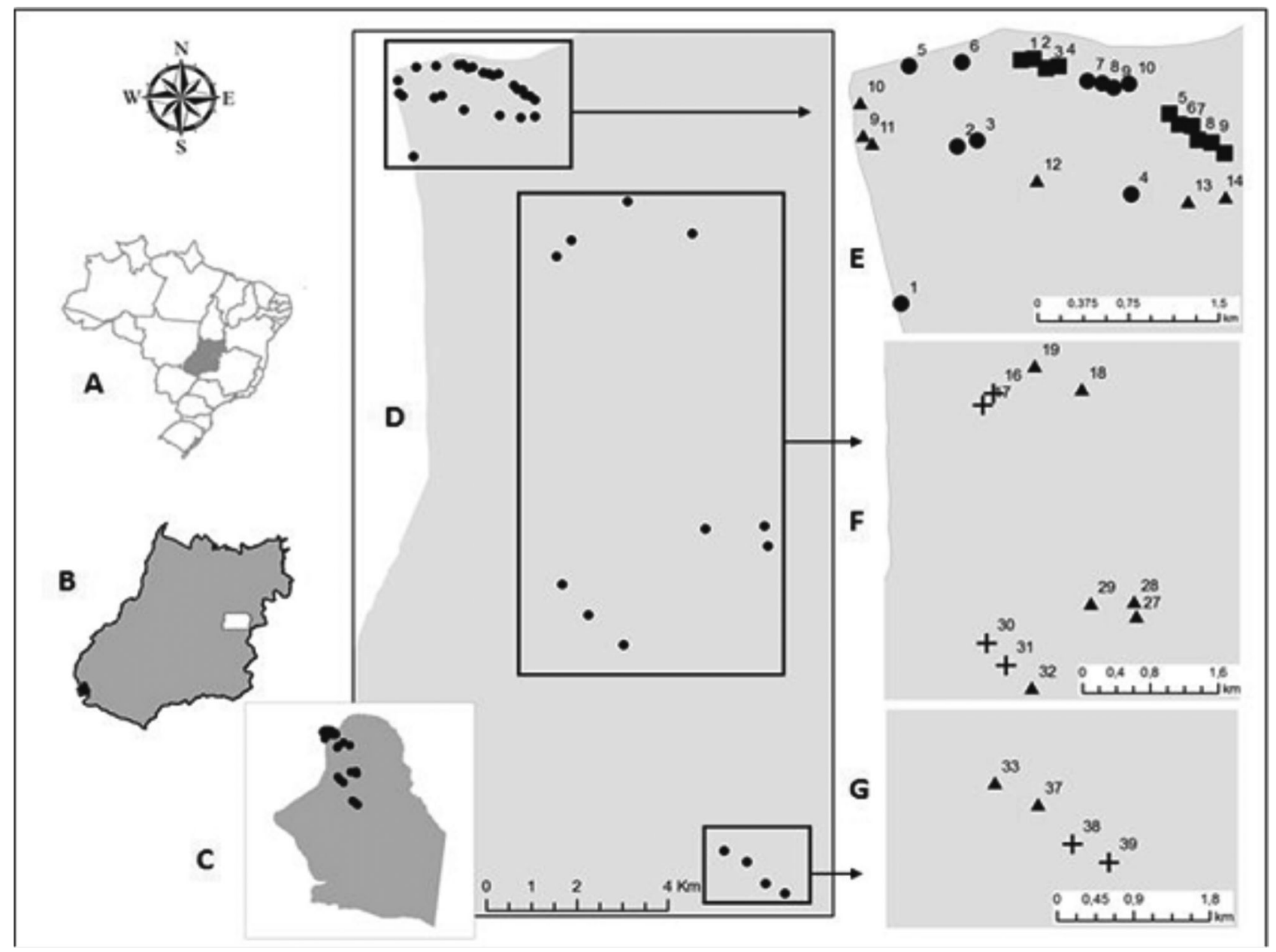

Figure 1. Map of Brazil showing Goiás State in black (a); map of Goiás State showing the Emas National Park (ENP) in black (b); area of the ENP showing the sample plots (black points, c); smaller scale of c (d); smaller scale of the squares indicated in d (e, f, g). The symbols indicate the vegetation type: semideciduous forest $(\boldsymbol{\square})$, cerrado sensu stricto $(\bullet)$, campo cerrado $(\mathbf{\Delta})$ and campo sujo $(+)$. The numbers represent the code of sample plots.

Table 1. Observed (Obs. rich.) and extrapolated richness (first order Jackknife, second order Jackknife and second order Chao) and percentage of extrapolated richness sampled in each phytophysiognomy (Phyto) and also in the total study area (ENP). In the first column, CS means campo sujo, CC campo cerrado, CSS cerrado sensu stricto, SF semideciduous forest and ENP, Emas National Park.

\begin{tabular}{lcccrrrr}
\hline Phyto & Obs. rich. & $\begin{array}{c}\text { Jackk 1 } \\
\pm \text { DP }\end{array}$ & $\begin{array}{c}\text { Jackk1 } \\
\text { rich. sampled }\end{array}$ & $\begin{array}{c}\text { Jackk 2 } \\
\pm \text { DP }\end{array}$ & $\begin{array}{c}\text { Jackk2 } \\
\text { rich. sampled }\end{array}$ & $\begin{array}{c}\text { Chao 2 } \\
\pm \text { DP }\end{array}$ & $\begin{array}{c}\text { Chao 2 } \\
\text { rich. sampled }\end{array}$ \\
\hline CS & 51 & $75.8 \pm 10.28$ & $68 \%$ & $86.6 \pm 16.3$ & $63 \%$ & $83.4 \pm 15.1$ & $65 \%$ \\
CC & 86 & $114.8 \pm 9.82$ & $75 \%$ & $128.7 \pm 18.5$ & $67 \%$ & $117 \pm 14.4$ & $74 \%$ \\
CSS & 98 & $132.2 \pm 12.08$ & $74 \%$ & $150.5 \pm 20.1$ & $65 \%$ & $140.4 \pm 18.3$ & $69 \%$ \\
SF & 98 & $132.2 \pm 12.08$ & $74 \%$ & $141 \pm 18.5$ & $70 \%$ & $123 \pm 10.4$ & $80 \%$ \\
ENP & $\mathbf{1 4 9}$ & $\mathbf{1 9 0 . 9} \pm \mathbf{9 . 4 6}$ & $\mathbf{7 8} \%$ & $\mathbf{2 1 4 . 1} \pm \mathbf{2 2 . 1}$ & $\mathbf{6 9 \%}$ & $\mathbf{1 9 7 . 6} \pm \mathbf{1 9 . 8}$ & $\mathbf{7 5 \%} \%$ \\
\hline
\end{tabular}

(5, 3\%), Pericopina (4, 2\%), Callimorphina and Eudesmiina (both with 1 species, 0.6\%) (Appendix 1).

It was estimated by first order Jackknife, second order Jackknife and second order Chao, that the sample region has a richness of approximately 190, 214 and 197 species respectively (Table 1). Fourteen species $(9 \%)$ were new records for the Cerrado, $47(31 \%)$ were new records for the State of Goiás and $101(67 \%)$ were new records for the ENP (Appendix 1). Cerrado 
68

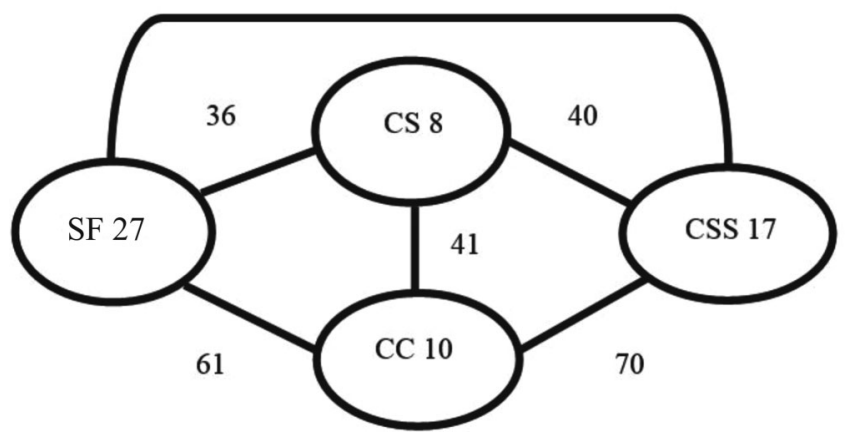

Figure 2. Venn diagram indicating the number of species that were sampled only in a vegetation type (numbers within the ellipses) and the number of shared species between vegetation types (numbers next to the lines). Campo sujo (CS), campo cerrado (CC), cerrado sensu stricto (CSS) and semideciduous forest (SF).

sensu stricto and semideciduous forest vegetation types had the highest species richness (98), followed by campo cerrado with 86 and campo sujo with 51 (Appendix 1).

About $41 \%$ of the sampled species $(n=62)$ occurred in only one vegetation type, $16 \%$ (25 species) occurred in two vegetation types, $18 \%$ (27 species) in three and $23 \%$ (35 species) occurred in all vegetation types (Appendix 1). The semideciduous forest had the highest number of exclusive species (27), followed by cerrado sensu stricto (17), campo cerrado (10) and campo sujo (eight) (Figure 2, Appendix 1). Campo cerrado and cerrado sensu stricto had more shared species and campo sujo and semideciduous forest had the least shared species (Figure 2, Appendix 1). Most species that occurred in three vegetation types $(88.8 \%)$ were shared between campo cerrado, cerrado sensu stricto, and semideciduous forest.

Some species ocurred in only one season (58 species ocurred only in the dry and 30 species only in the rainy season) and the others species in both seasons $(\mathrm{N}=61)$. The dry showed more species $(\mathrm{N}=119)$ than the rainy season $(\mathrm{N}=91)$ (Appendix 1$)$.

\section{Discussion}

The ENP Arctiinae fauna represents approximately $20 \%$ of the species recorded for the Cerrado (Ferro et al. 2010) and $10 \%$ of species recorded from Brazil (Ferro \& Diniz 2010). The previous Cerrado Arctiinae richness (Ferro \& Diniz 2010) is replaced by 737 species, with the addition of 14 new records for the biome. The fauna of the ENP is the second richest locality in the Cerrado, after Brasilia (222 species, Ferro \& Diniz 2010). The richness observed in the ENP (149 species) was similar to the other intensively sampled areas in the Cerrado, such as Vilhena (136) and Chapada dos Guimarães (129) (Ferro \& Diniz 2010), and Rain Forest sites, such as São José dos Ausentes (121) (Ferro \& Romanowski 2012), La Selva Biological Station (148) (Brehm 2007), and São Bento do Sul (162) (Ferro et al. 2012). However, Hilt \& Fiedler (2005) observed a significantly greater tiger moth richness in Ecuador (287 species).

This high richness, the large number of new distribution records (including 14 for the Cerrado), and the existence of at least another 40 species in the study area (according to the first order Jackknife estimator), reinforces the importance of conserving the ENP and its surroundings. Despite being well preserved, the ENP is a large fragment surrounded by extensive monocultures of soybean, corn, cotton and sugarcane matrix. These monocultures can act as a barrier to the dispersal of individuals and hence cause problems associated with small, isolated populations, such as inbreeding, genetic drift and increased susceptibility to future stochastic events. Furthermore, the use of insecticides on these crops can cause increased mortality of insects at the edges of the park, affecting, for example, pollination of entomophilous plants. Moreover, the invasion of alien species such as Brachiaria can reduce the natural vegetation due to competition among species (Almeida-Neto et al. 2010), for example, which results in a lower availability of host plants. All of these factors can affect the assemblages of insect herbivores and pollinators. Thus, among the priority actions for the conservation of the ENP (and its surroundings) Arctiinae fauna are the creation of new protected areas in their surroundings and the creation of ecological corridors between protected areas for the fauna of the region (Rodrigues et al. 2002).

The semideciduous forest had the highest number of exclusive species in relation to other vegetation types. This result can be explained by the fact that this vegetation type has a different microclimate, plant species and soil types than cerrado sensu lato (Oliveira-Filho \& Ratter 2002, Ruggiero et al. 2002).

Both seasons presented exclusive species, but this was more evident in the dry season. The dry presented more Arctiinae species than the rainy season, as found for other Lepidoptera species (Morais et al. 1999, Pinheiro et al. 2002). In Cerrado biome, the dry winter season is marked by adverse conditions, like low humidity and cold temperature (Ramos-Neto \& Pivello 2000). Also, the vegetation faces a water deficit and a reduction in nutritional quality in this season (Ramos-Neto \& Pivello 2000, Pinheiro et al. 2002) and it can affect the Arctiinae moths, as they depend on the plants, both in larval (herbivorous) and in adult (pollinator) phases. Thus, we believe that the more Arctiinae species found in the winter dry season must be due to a temporarily enemy-free space (Jeffries \& Lawton 1984, Morais et al. 1999). In this period, the predators and parasitoids should be less abundant than in the rainy season (Morais et al. 1999) and it should enable more Arctiinae species to coexist in the severe dry season.

The Cerrado biome has diminished in recent decades mainly due to agricultural expansion (Klink \& Machado 2005). Many species may have been lost in this process, including species not yet known to science. According to Ferro et al. (2010), much of the biome has not yet been inventoried. Thus, studies that generate lists of species, especially in places rarely or never sampled regarding the fauna, are urgent and very important to understand the biodiversity. Furthermore, these data improve our estimation of the geographical distribution and the status (e.g. rare, endemic, threatened) of species. These data, therefore, can be analyzed by niche modeling and guide future conservation strategies, such as the location of new conservation units. However, these estimates will be much more accurate if natural history data are included and if the species identification is correct. 
Appendix 1. List of Actiinae moth species sampled in four phytophysiognomies of the Emas National Park (ENP), in the dry and rainy seasons. CS means campo sujo, CC campo cerrado, CSS cerrado sensu stricto and SF semideciduous forest. Species with symbols ${ }^{\# *}$ are new records for Cerrado, ${ }^{\# \$}$ for Goias State and ${ }^{\#}$ for ENP.

\begin{tabular}{|c|c|c|c|c|c|c|}
\hline \multirow[b]{2}{*}{ Species } & \multicolumn{4}{|c|}{ Phytophysiognomy } & \multicolumn{2}{|c|}{ Season } \\
\hline & CS & $\mathbf{C C}$ & CSS & SF & Dry & Rainy \\
\hline \multicolumn{7}{|l|}{ Arctiinae } \\
\hline \multicolumn{7}{|l|}{ Arctiini } \\
\hline Arctiinii sp.1 & & $\mathrm{x}$ & $\mathrm{x}$ & $\mathrm{x}$ & $\mathrm{x}$ & \\
\hline Arctiinii sp. 2 & & & $\mathrm{x}$ & & $\mathrm{x}$ & \\
\hline Arctiinii sp.3 & & & $\mathrm{x}$ & $\mathrm{x}$ & & $\mathrm{X}$ \\
\hline Arctiinii sp.4 & & $\mathrm{x}$ & & & & $\mathrm{x}$ \\
\hline Ctenuchiini sp.1 & $\mathrm{x}$ & $\mathrm{x}$ & & & & $\mathrm{x}$ \\
\hline \multicolumn{7}{|l|}{ Arctiina } \\
\hline Hypercompe mus (Oberthür, 1881) & & & $\mathrm{x}$ & & & $\mathrm{X}$ \\
\hline Paracles phaeocera (Hampson, 1905) & & $\mathrm{x}$ & $\mathrm{x}$ & & $\mathrm{x}$ & $\mathrm{x}$ \\
\hline Paracles sp.1 & $\mathrm{x}$ & $\mathrm{x}$ & $\mathrm{x}$ & $\mathrm{x}$ & $\mathrm{x}$ & $\mathrm{x}$ \\
\hline Paracles sp. 2 & & & $\mathrm{x}$ & & $\mathrm{x}$ & \\
\hline Pseudalus limona Schaus, 1896\# & $\mathrm{x}$ & $\mathrm{x}$ & $\mathrm{x}$ & $\mathrm{x}$ & & $\mathrm{X}$ \\
\hline \multicolumn{7}{|l|}{ Callimorphina } \\
\hline Utetheisa ornatrix (Linnaeus, 1758) & $\mathrm{x}$ & $\mathrm{x}$ & $\mathrm{x}$ & $\mathrm{x}$ & $\mathrm{x}$ & $\mathrm{x}$ \\
\hline \multicolumn{7}{|l|}{ Ctenuchina } \\
\hline Aclytia flavigutta (Walker, 1854) $\# \$$ & $\mathrm{x}$ & $\mathrm{x}$ & $\mathrm{x}$ & $\mathrm{x}$ & $\mathrm{x}$ & $\mathrm{X}$ \\
\hline Aclytia heber (Cramer, 1780) & $\mathrm{x}$ & $\mathrm{x}$ & $\mathrm{x}$ & $\mathrm{x}$ & $\mathrm{x}$ & $\mathrm{x}$ \\
\hline Aclytia sp.1 & & $\mathrm{x}$ & $\mathrm{x}$ & $\mathrm{x}$ & $\mathrm{x}$ & \\
\hline Argyroeides braco (Herrich-Schäffer, [1855] ${ }^{\#}$ & & & & $\mathrm{x}$ & $\mathrm{x}$ & \\
\hline Cercopimorpha postflavia Rothschild, $1912^{\# \$}$ & & & & $\mathrm{x}$ & $\mathrm{x}$ & \\
\hline Correbidia calopteridia (Butler, 1878) & & & & $\mathrm{x}$ & $\mathrm{x}$ & \\
\hline Correbidia sp.1 & & & & $\mathrm{x}$ & $\mathrm{x}$ & \\
\hline Delphyre discalis (Druce, 1905)\# & $\mathrm{x}$ & $\mathrm{x}$ & $\mathrm{x}$ & $\mathrm{x}$ & $\mathrm{x}$ & $\mathrm{X}$ \\
\hline Delphyre dizona (Druce, 1898) & $\mathrm{x}$ & $\mathrm{x}$ & $\mathrm{x}$ & $\mathrm{x}$ & $\mathrm{x}$ & $\mathrm{x}$ \\
\hline Episcepsis klagesi Rothschild, $1911^{\# \$}$ & & & $\mathrm{x}$ & & $\mathrm{x}$ & \\
\hline Episcepsis lenaeus (Cramer, 1780) & & & $\mathrm{x}$ & & $\mathrm{x}$ & \\
\hline Episcepsis thetis (Linnaeus, 1771) & & & $\mathrm{x}$ & $\mathrm{x}$ & $\mathrm{x}$ & \\
\hline Eucereon albidia Rothschild, $1912^{\# \$^{*}}$ & & & $\mathrm{x}$ & $\mathrm{x}$ & $\mathrm{x}$ & \\
\hline Eucereon arenosun Butler, $1877^{\# \$}$ & $\mathrm{x}$ & & & & & $\mathrm{x}$ \\
\hline Eucereon dorsipuncta Hampson, $1905^{\#}$ & & & $\mathrm{x}$ & $\mathrm{x}$ & $\mathrm{x}$ & \\
\hline Eucereon pseudarchias Hampson, $1898^{\# \$}$ & & & & $\mathrm{x}$ & $\mathrm{x}$ & \\
\hline Eucereon setosum $(\text { Sepp, }[1830])^{\# \$}$ & & $\mathrm{x}$ & $\mathrm{x}$ & $\mathrm{x}$ & $\mathrm{x}$ & $\mathrm{x}$ \\
\hline Eucereon sp.1 & & $\mathrm{x}$ & $\mathrm{x}$ & $\mathrm{x}$ & $\mathrm{x}$ & $\mathrm{x}$ \\
\hline Heliura rhodophila (Walker, 1856) & & & $\mathrm{x}$ & & & $\mathrm{x}$ \\
\hline Heliura tetragramma (Walker, 1854) & $\mathrm{x}$ & $\mathrm{x}$ & $\mathrm{x}$ & $\mathrm{x}$ & $\mathrm{x}$ & $\mathrm{x}$ \\
\hline Napata leucotela Butler, 1876\# & $\mathrm{x}$ & & & & $\mathrm{x}$ & \\
\hline Philoros rubriceps (Walker, 1854) & $\mathrm{x}$ & $\mathrm{x}$ & $\mathrm{x}$ & & $\mathrm{x}$ & $\mathrm{x}$ \\
\hline Pseudohyaleucerea vulnerata (Butler, 1875) & & & & $\mathrm{x}$ & $\mathrm{x}$ & \\
\hline Pseudosphex discoplaga (Schaus, 1905) & & & $\mathrm{x}$ & & $\mathrm{x}$ & \\
\hline Pseudosphex fulvisphex (Druce, 1898) & & $\mathrm{x}$ & $\mathrm{x}$ & $\mathrm{x}$ & $\mathrm{x}$ & \\
\hline Pseudosphex nivaca (Jones, 1914) & $\mathrm{x}$ & $\mathrm{x}$ & $\mathrm{x}$ & $\mathrm{x}$ & $\mathrm{x}$ & $\mathrm{x}$ \\
\hline \multicolumn{7}{|l|}{ Euchromiina } \\
\hline Autochloris enagrus (Cramer, 1780) ${ }^{\# \$^{*}}$ & & $\mathrm{x}$ & $\mathrm{x}$ & & $\mathrm{x}$ & $\mathrm{x}$ \\
\hline Cosmosoma achemon (Fabricius, 1781) & $\mathrm{x}$ & $\mathrm{x}$ & $\mathrm{x}$ & $\mathrm{x}$ & $\mathrm{x}$ & $\mathrm{x}$ \\
\hline Cosmosoma auge (Linnaeus, 1767) & & $\mathrm{x}$ & & $\mathrm{x}$ & $\mathrm{x}$ & \\
\hline Cosmosoma nigriscens Rothschild, $1911^{\#}$ & & $\mathrm{x}$ & & & $\mathrm{x}$ & \\
\hline Cosmosoma rasera Jones, $1914^{\#}$ & & $\mathrm{x}$ & $\mathrm{x}$ & $\mathrm{x}$ & $\mathrm{x}$ & $\mathrm{X}$ \\
\hline Cosmosoma theuthras restrictum Butler, $1876^{\#}$ & $\mathrm{x}$ & $\mathrm{x}$ & $\mathrm{x}$ & $\mathrm{x}$ & $\mathrm{x}$ & $\mathrm{x}$ \\
\hline Cosmosoma sp. 1 & & $\mathrm{x}$ & $\mathrm{x}$ & $\mathrm{x}$ & $\mathrm{x}$ & $\mathrm{x}$ \\
\hline Cosmosoma sp. 2 & $\mathrm{x}$ & & & & $\mathrm{x}$ & \\
\hline Cosmosoma sp. 3 & $\mathrm{x}$ & & $\mathrm{x}$ & $\mathrm{x}$ & $\mathrm{x}$ & $\mathrm{x}$ \\
\hline Dycladia lucetius (Stoll, 1781) & $\mathrm{x}$ & $\mathrm{x}$ & $\mathrm{x}$ & $\mathrm{x}$ & $\mathrm{x}$ & $\mathrm{x}$ \\
\hline Erruca hanga (Herrich-Schäffer, [1854]) & $\mathrm{x}$ & & & & & $\mathrm{x}$ \\
\hline Eurota histrio (Guérin, 1843) & & & $\mathrm{x}$ & & $\mathrm{x}$ & \\
\hline
\end{tabular}




\begin{tabular}{|c|c|c|c|c|c|c|}
\hline \multirow[b]{2}{*}{ Species } & \multicolumn{4}{|c|}{ Phytophysiognomy } & \multicolumn{2}{|c|}{ Season } \\
\hline & CS & $\mathbf{C C}$ & CSS & SF & Dry & Rainy \\
\hline Eurota nigricincta Hampson, $1907^{\# \$}$ & $\mathrm{x}$ & & & & $\mathrm{x}$ & \\
\hline Hyda basilutea (Walker, 1854) & & $\mathrm{x}$ & $\mathrm{x}$ & & $\mathrm{x}$ & $\mathrm{x}$ \\
\hline Lepidoneiva erubescens (Butler, 1876) & $\mathrm{x}$ & $\mathrm{x}$ & $\mathrm{x}$ & $\mathrm{x}$ & $\mathrm{x}$ & $\mathrm{x}$ \\
\hline Macrocneme aurifera Hampson, $1914^{\# \$^{*}}$ & $\mathrm{x}$ & $\mathrm{x}$ & $\mathrm{x}$ & $\mathrm{x}$ & $\mathrm{x}$ & $\mathrm{x}$ \\
\hline Nyridela acroxantha (Perty, 1833) & & $\mathrm{x}$ & & $\mathrm{x}$ & $\mathrm{x}$ & $\mathrm{x}$ \\
\hline Nyridela chalciope (Hübner, [1827]) & & & $\mathrm{x}$ & & & $\mathrm{x}$ \\
\hline Pheia albisigna (Walker, 1854) & $\mathrm{x}$ & $\mathrm{x}$ & $\mathrm{x}$ & $\mathrm{x}$ & $\mathrm{x}$ & $\mathrm{x}$ \\
\hline Pheia gaudens (Walker, 1856) & & $\mathrm{x}$ & & & $\mathrm{x}$ & \\
\hline Pheia haematosticta Jones, 1908 & $\mathrm{x}$ & $\mathrm{x}$ & $\mathrm{x}$ & $\mathrm{x}$ & $\mathrm{x}$ & $\mathrm{x}$ \\
\hline Pheia haemopera Schaus, 1898 & $\mathrm{x}$ & $\mathrm{x}$ & $\mathrm{x}$ & $\mathrm{x}$ & $\mathrm{x}$ & $\mathrm{x}$ \\
\hline Pheia seraphina (Herrich-Schäffer, 1854) & $\mathrm{x}$ & $\mathrm{x}$ & $\mathrm{x}$ & $\mathrm{x}$ & $\mathrm{x}$ & $\mathrm{x}$ \\
\hline Pheia sp.1 & $\mathrm{x}$ & & $\mathrm{x}$ & & & $\mathrm{x}$ \\
\hline Phoenicoprocta baeri Rothschild, 1911 & $\mathrm{x}$ & $\mathrm{x}$ & $\mathrm{x}$ & $\mathrm{x}$ & & $\mathrm{x}$ \\
\hline Phoenicoprocta $\mathrm{sp} .1$ & & $\mathrm{x}$ & $\mathrm{x}$ & $\mathrm{x}$ & & $\mathrm{x}$ \\
\hline Poliopastea plumbea Hampson, $1898^{\# \$}$ & $\mathrm{x}$ & $\mathrm{x}$ & $\mathrm{x}$ & & $\mathrm{x}$ & $\mathrm{x}$ \\
\hline Poliopastea sp.1 & & & & $\mathrm{x}$ & $\mathrm{x}$ & \\
\hline Saurita attenuata Hampson, $1905^{\# \$^{*}}$ & & & & $\mathrm{x}$ & $\mathrm{x}$ & $\mathrm{x}$ \\
\hline Sphecosoma aenetus (Schaus, 1896) & & & $\mathrm{x}$ & & & $\mathrm{x}$ \\
\hline \multicolumn{7}{|l|}{ Pericopina } \\
\hline Dysschema boisduvalli (van der Hoeven \& de Vriese, 1840) & $\mathrm{x}$ & & & & & $\mathrm{x}$ \\
\hline Dysschema sacrifica (Hübner, [1831]) & & $\mathrm{x}$ & $\mathrm{x}$ & $\mathrm{x}$ & & $\mathrm{x}$ \\
\hline Hyalurga fenestra (Linnaeus, 1758) & & & $\mathrm{x}$ & & $\mathrm{x}$ & \\
\hline Hyalurga partita (Walker, 1854) & & & & $\mathrm{x}$ & $\mathrm{x}$ & \\
\hline \multicolumn{7}{|l|}{ Phaegopterina } \\
\hline Agaraea semivitrea Rothschild, $1909^{\#}$ & & & & $\mathrm{x}$ & & $\mathrm{x}$ \\
\hline Amaxia dyuna Schaus, $1896^{\# \$}$ & $\mathrm{x}$ & $\mathrm{x}$ & $\mathrm{x}$ & $\mathrm{x}$ & $\mathrm{x}$ & $\mathrm{x}$ \\
\hline Amaxia kennedyi (Rothschild, 1909) & & & & $\mathrm{x}$ & $\mathrm{x}$ & \\
\hline Bertholdia detracta Seitz, $1921^{\#}$ & $\mathrm{x}$ & & & & $\mathrm{x}$ & \\
\hline Biturix diversipes (Walker, 1855) ${ }^{\# \$^{*}}$ & & $\mathrm{x}$ & & & $\mathrm{x}$ & \\
\hline Carales astur (Cramer, 1777) & & & & $\mathrm{x}$ & $\mathrm{x}$ & \\
\hline Cresera affinis (Rothschild, 1909) & & & & $\mathrm{x}$ & $\mathrm{x}$ & \\
\hline Cresera ilioides (Schaus, 1905) & & $\mathrm{x}$ & & & $\mathrm{x}$ & \\
\hline Cresera optima (Butler, 1877) & & & & $\mathrm{x}$ & $\mathrm{x}$ & $\mathrm{x}$ \\
\hline Echeta juno (Schaus, 1892) & & & & $\mathrm{x}$ & & $\mathrm{x}$ \\
\hline Elysius hermia (Cramer, 1777) & & & $\mathrm{x}$ & & $\mathrm{x}$ & \\
\hline Elysius joiceyi Talbot, $1928^{\#}$ & $\mathrm{x}$ & $\mathrm{x}$ & $\mathrm{x}$ & & & $\mathrm{x}$ \\
\hline Eupseudosoma grandis Rothschild, $1909^{\# \$}$ & $\mathrm{x}$ & $\mathrm{x}$ & $\mathrm{x}$ & $\mathrm{x}$ & $\mathrm{x}$ & \\
\hline Eupseudosoma involuta $($ Sepp, [1855]) & & & $\mathrm{x}$ & $\mathrm{x}$ & $\mathrm{x}$ & \\
\hline Halysidota sannionis (Rothschild, 1909) & & $\mathrm{x}$ & $\mathrm{x}$ & $\mathrm{x}$ & $\mathrm{x}$ & $\mathrm{x}$ \\
\hline Hyperandra appendiculata (Herrich-Schäffer, [1856]) & & & & $\mathrm{x}$ & $\mathrm{x}$ & \\
\hline Hyperthaema sp.1 & & $\mathrm{x}$ & $\mathrm{x}$ & $\mathrm{x}$ & $\mathrm{x}$ & $\mathrm{x}$ \\
\hline Hyperthaema sp. 2 & & $\mathrm{x}$ & $\mathrm{x}$ & & $\mathrm{x}$ & $\mathrm{x}$ \\
\hline Hyponerita lavinia (Druce, 1890 ) & $\mathrm{x}$ & & & & & $\mathrm{x}$ \\
\hline Idalus agricus Dyar, $1910^{\# \$^{*}}$ & & $\mathrm{x}$ & $\mathrm{x}$ & $\mathrm{x}$ & $\mathrm{x}$ & \\
\hline Idalus carinosa (Schaus, 1905) & $\mathrm{x}$ & $\mathrm{x}$ & $\mathrm{x}$ & $\mathrm{x}$ & $\mathrm{x}$ & $\mathrm{x}$ \\
\hline Idalus citrina Druce, $1890^{\# \$}$ & $\mathrm{x}$ & $\mathrm{x}$ & $\mathrm{x}$ & $\mathrm{x}$ & $\mathrm{x}$ & $\mathrm{x}$ \\
\hline Idalus dares Druce, $1894^{\#}$ & & $\mathrm{x}$ & & & $\mathrm{x}$ & \\
\hline Idalus lineosus Walker, $1869^{\#}$ & & $\mathrm{x}$ & $\mathrm{x}$ & & $\mathrm{x}$ & $\mathrm{x}$ \\
\hline Lepidokirbyia vittipes (Walker, 1855) & & $\mathrm{x}$ & $\mathrm{x}$ & $\mathrm{x}$ & $\mathrm{x}$ & $\mathrm{x}$ \\
\hline Leucanopsis rosetta (Schaus, 1896) & $\mathrm{x}$ & $\mathrm{x}$ & $\mathrm{x}$ & $\mathrm{x}$ & & $\mathrm{x}$ \\
\hline Leucanopsis squalida (Herrich-Schäffer, [1855]) & & $\mathrm{x}$ & $\mathrm{x}$ & & & $\mathrm{x}$ \\
\hline Leucanopsis strigulosa (Walker, 1855) & $\mathrm{x}$ & $\mathrm{x}$ & $\mathrm{x}$ & $\mathrm{x}$ & $\mathrm{x}$ & $\mathrm{x}$ \\
\hline Lophocampa annulosa (Walker, 1855) & & & $\mathrm{x}$ & & $\mathrm{x}$ & \\
\hline Lophocampa atrimaculata (Hampson, 1901) & & & & $\mathrm{x}$ & $\mathrm{x}$ & \\
\hline Lophocampa citrina $($ Sepp, [1852]) & & $\mathrm{x}$ & $\mathrm{x}$ & $\mathrm{x}$ & $\mathrm{x}$ & $\mathrm{x}$ \\
\hline Mazaeras francki Schaus, $1896^{\#}$ & & $\mathrm{x}$ & & & & $\mathrm{x}$ \\
\hline Melese incertus (Walker, 1855) & & $\mathrm{x}$ & $\mathrm{x}$ & & $\mathrm{x}$ & \\
\hline
\end{tabular}




\begin{tabular}{|c|c|c|c|c|c|c|}
\hline \multirow[b]{2}{*}{ Species } & \multicolumn{4}{|c|}{ Phytophysiognomy } & \multicolumn{2}{|c|}{ Season } \\
\hline & CS & $\mathbf{C C}$ & CSS & SF & Dry & Rainy \\
\hline Melese paranensis Dognin, $1911^{\# \$}$ & & & & $\mathrm{x}$ & $\mathrm{x}$ & $\mathrm{x}$ \\
\hline Neritos atta Schaus, $1920^{\# \$}$ & & $\mathrm{x}$ & $\mathrm{x}$ & $\mathrm{x}$ & $\mathrm{x}$ & \\
\hline Neritos flavimargo Joicey \& Talbot, 1916 & & $\mathrm{x}$ & $\mathrm{x}$ & & $\mathrm{x}$ & \\
\hline Neritos hampsoni Rothschild, $1909^{\# \$}$ & & & $\mathrm{x}$ & $\mathrm{x}$ & $\mathrm{x}$ & $\mathrm{x}$ \\
\hline Neritos sanguipuncta Schaus, $1901^{\#}$ & & & & $\mathrm{x}$ & $\mathrm{x}$ & \\
\hline Pareuchaetes aurata (Butler, 1875) & $\mathrm{x}$ & $\mathrm{x}$ & $\mathrm{x}$ & $\mathrm{x}$ & $\mathrm{x}$ & $\mathrm{x}$ \\
\hline Pelochyta arontes $($ Stoll, 1782) & & & & $\mathrm{x}$ & $\mathrm{x}$ & \\
\hline Psychophasma erosa (Herrich-Schäffer, [1858]) & & $x$ & & $\mathrm{x}$ & $\mathrm{x}$ & \\
\hline Rhipha pulcherrima (Rothschild, 1935) & $\mathrm{x}$ & $\mathrm{x}$ & $\mathrm{x}$ & $\mathrm{x}$ & & $\mathrm{x}$ \\
\hline Rhipha strigosa (Walker, 1854) & & & $\mathrm{x}$ & & $\mathrm{x}$ & $\mathrm{x}$ \\
\hline Robinsonia dewitzi Gundlach, $1881^{\# \$}$ & & $\mathrm{x}$ & & & $\mathrm{x}$ & \\
\hline Scaptius submarginalis (Rothschild, 1909) $\#{ }^{* *}$ & & & & $\mathrm{x}$ & $\mathrm{x}$ & \\
\hline Viviennea salma (Druce, 1896) & & $\mathrm{x}$ & $\mathrm{x}$ & & $\mathrm{x}$ & $\mathrm{x}$ \\
\hline \multicolumn{7}{|l|}{ Lithosiini } \\
\hline Lithosiinii sp. 1 & & & $\mathrm{x}$ & $\mathrm{x}$ & & $\mathrm{x}$ \\
\hline Lithosiinii sp. 2 & & $\mathrm{x}$ & $\mathrm{x}$ & $\mathrm{x}$ & $\mathrm{x}$ & $\mathrm{x}$ \\
\hline Lithosiinii sp. 3 & & $\mathrm{x}$ & $\mathrm{x}$ & $\mathrm{x}$ & $\mathrm{x}$ & \\
\hline Lithosiinii sp. 4 & $\mathrm{x}$ & $\mathrm{x}$ & & & $\mathrm{x}$ & \\
\hline Lithosiinii sp. 5 & & & $\mathrm{x}$ & & $\mathrm{x}$ & \\
\hline Lithosiinii sp. 6 & & & & $\mathrm{x}$ & $\mathrm{x}$ & \\
\hline Lithosiinii sp. 7 & & & & $\mathrm{x}$ & $\mathrm{x}$ & \\
\hline Lithosiinii sp. 8 & & $\mathrm{x}$ & $\mathrm{x}$ & $\mathrm{x}$ & $\mathrm{x}$ & $\mathrm{x}$ \\
\hline Lithosiinii sp. 9 & & & & $\mathrm{x}$ & $\mathrm{x}$ & \\
\hline Lithosiinii sp. 12 & & & $\mathrm{x}$ & & & $\mathrm{x}$ \\
\hline Lithosiinii sp. 14 & $\mathrm{x}$ & $\mathrm{x}$ & $\mathrm{x}$ & $\mathrm{x}$ & $\mathrm{x}$ & $\mathrm{x}$ \\
\hline \multicolumn{7}{|l|}{ Cisthenina } \\
\hline Barsinella mirabilis Butler, 1878 & & & $\mathrm{x}$ & $\mathrm{x}$ & $\mathrm{x}$ & $\mathrm{x}$ \\
\hline Cisthene dives (Schaus, 1896) & & $\mathrm{x}$ & $\mathrm{x}$ & $\mathrm{x}$ & $\mathrm{x}$ & \\
\hline Cisthene ruficollis (Schaus, 1896) & & $\mathrm{x}$ & & & & $\mathrm{x}$ \\
\hline Cisthene subruba (Schaus, 1905) & $\mathrm{x}$ & $\mathrm{x}$ & $\mathrm{x}$ & $\mathrm{x}$ & $\mathrm{x}$ & $\mathrm{x}$ \\
\hline Cisthene triplaga (Hampson, 1905) & $\mathrm{x}$ & $\mathrm{x}$ & $\mathrm{x}$ & $\mathrm{x}$ & $\mathrm{x}$ & $\mathrm{x}$ \\
\hline Cisthene sp.1 & & $\mathrm{x}$ & $\mathrm{x}$ & $\mathrm{x}$ & $\mathrm{x}$ & $\mathrm{x}$ \\
\hline Cisthene sp. 2 & & $\mathrm{x}$ & $\mathrm{x}$ & $\mathrm{x}$ & & $\mathrm{x}$ \\
\hline Cisthene sp. 3 & & & $\mathrm{x}$ & $\mathrm{x}$ & & $\mathrm{x}$ \\
\hline Illice croesus Hampson, 1914 & & $\mathrm{x}$ & & & $\mathrm{x}$ & \\
\hline Illice griseola (Rothschild, 1913) & & & & $\mathrm{x}$ & $\mathrm{x}$ & \\
\hline Odozana domina (Schaus, 1896) & & $\mathrm{x}$ & $\mathrm{x}$ & $\mathrm{x}$ & $\mathrm{x}$ & $\mathrm{x}$ \\
\hline Odozana obscura (Schaus, 1896) & $\mathrm{x}$ & $\mathrm{x}$ & $\mathrm{x}$ & $\mathrm{x}$ & $\mathrm{x}$ & $\mathrm{x}$ \\
\hline Talara grisea Schaus, $1896^{\#}$ & & $\mathrm{x}$ & $\mathrm{x}$ & $\mathrm{x}$ & $\mathrm{x}$ & $\mathrm{x}$ \\
\hline \multicolumn{7}{|l|}{ Eudesmiina } \\
\hline Antona fallax (Butler, 1877) & & & $\mathrm{x}$ & & & $\mathrm{x}$ \\
\hline \multicolumn{7}{|l|}{ Lithosina } \\
\hline Agylla argentea $(\text { Walker, } 1863)^{\# \$^{*}}$ & $\mathrm{x}$ & $\mathrm{x}$ & $\mathrm{x}$ & $\mathrm{x}$ & $\mathrm{x}$ & $\mathrm{x}$ \\
\hline Agylla marcata (Schaus, 1894) & $\mathrm{x}$ & $\mathrm{x}$ & & & $\mathrm{x}$ & $\mathrm{x}$ \\
\hline Agylla sp.1 & $\mathrm{x}$ & $\mathrm{x}$ & $\mathrm{x}$ & $\mathrm{x}$ & $\mathrm{x}$ & $\mathrm{x}$ \\
\hline Apistosia judas Hübner, [1819] & & & & $\mathrm{x}$ & & $\mathrm{x}$ \\
\hline Metalobosia diaxantha Hampson, $1914^{\#}$ & & & & $\mathrm{x}$ & $\mathrm{x}$ & $\mathrm{x}$ \\
\hline Nodozana jucunda Jones, 1914 & $\mathrm{x}$ & $\mathrm{x}$ & $\mathrm{x}$ & $\mathrm{x}$ & $\mathrm{x}$ & $\mathrm{x}$ \\
\hline Parablavia sadima (Schaus, 1896) & $\mathrm{x}$ & $\mathrm{x}$ & $\mathrm{x}$ & $\mathrm{x}$ & $\mathrm{x}$ & $\mathrm{x}$ \\
\hline
\end{tabular}

\section{Acknowledgments}

Vanessa Grandolfo, Taynara Nascimento (in memoriam), Luiz Rezende, Luciano Sgarbi, Carolina Caiado, Adriano Jaskulski, Murilo Menezes, Karen Neves, Amanda Honório, Verônica Bernardino, Ângela Soares, Vidal Cobos, Hauanny Rodrigues, Silas Bittencourt, Balwer Pimentel, Letícia Gomes,
Matheus Alves and Tainã Cardoso helped in field sampling. Dr. Victor Becker helped in species identification. This research was funded by Site 13 (Emas National Park) of the Brazilian Long Term Ecological Research Network (CNPq, grant 558187/ 2009-9) and SISBIOTA-Brasil (RedeLep; CNPq, grant 563332/ 2010-7). CM receives a student fellowship from the Coordenação de Aperfeiçoamento de Pessoal de Nível Superior (CAPES). 


\section{References}

ALMEIDA-NETO, M., PRADO, P.I., KUBOTA, U., BARIANI, J.M., AGUIRRE, G.H. \& LEWINSOHN, T.M. 2010. Invasive grasses and native Asteraceae in the Brazilian Cerrado. Plant. Ecol. 209(1): 109-122, http://dx.doi.org/10.1007/s11258-010-9727-8

BINI, L.M., DINIZ-FILHO, J.A.F., RANGEL, T.F.L.V.B., BASTOS, R.P. \& PINTO, M.P. 2006. Chalenging Wallacean and Linnean shortfalls: knowledge gradients and conservation planning in a biodiversity hotspot. Diversity Distrib. 12:475-482, http://dx.doi.org/10.1111/j.1366-9516.2006.00286.x

BREHM, G. 2007. Contrasting patterns of vertical stratification in two moth families in a Costa Rican lowland rain forest. Basic Appl. Ecol. 8(1):44-54, http://dx.doi.org/10.1016/j.baae.2006.02.002

FERRO, V.G. \& DINIZ, I.R. 2007. Composition of the Arctiidae species (Insecta, Lepidoptera) in Cerrado areas. Rev. Bras. Zool. 24(3): 635-646, http://dx.doi.org/10.1590/S0101-81752007000300015

FERRO, V.G. \& DINIZ, I.R. 2010. Riqueza e composição de mariposas Arctiidae (Lepidoptera) no Cerrado. In Cerrado, Conhecimento científico quantitativo como subsídio para ações de conservação (I.R. Diniz, J. Marinho-Filho, R.B. Machado \& R.B. Cavalcanti, eds). Thesaurus, Brasília, p. 255-313.

FERRO, V.G., MELO, A.S. \& DINIZ, I.R. 2010. Richness of tiger moths (Lepidoptera: Arctiidae) in the Brazilian Cerrado: how much do we know? Zoologia. 27(5):725-731, http://dx.doi.org/10.1590/S1984-4670 2010000500009

FERRO, V.G., RESENDE, I.M.H. \& DUARTE, M. 2012. The Arctiinae moths (Lepidoptera: Erebidae) of Santa Catarina state, Brazil. Biota Neotrop. 12(4):166-180, http://dx.doi.org/10.1590/ S1676-06032012000400018

FERRO, V.G. \& ROMANOWSKI, H.P. 2012. Diversity and composition of tiger moths (Lepidoptera: Arctiidae) in an area of Atlantic Forest in southern Brazil: is the fauna more diverse in the grassland or in the forest? Zoologia. 29(1):7-18, http://dx.doi.org/10.1590/S1984-46702012 000100002

FRANÇA, H., RAMOS-NETO, M.B. \& SETZER, A. 2007. O fogo no Parque Nacional das Emas. Ministério do Meio Ambiente, Brasília.

HAMPSON, G.F. 1898. Catalogue of the Lepidoptera Phalaenae in the British Museum. Order of the Trustees, London.

HAMPSON, G.F. 1900. Catalogue of the Lepidoptera Phalaenae in the British Museum. Order of the Trustees, London.

HAMPSON, G.F. 1901. Catalogue of the Lepidoptera Phalaenae in the British Museum. Order of the Trustees, London.

HAMPSON, G.F. 1914. Catalogue of the Lepidoptera Phalaenae in the British Museum. Order of the Trustees, London.

HAUSER, C.L. \& BOPPRÉ, M. 1997. A revision of the Afrotropical taxa of the genus Amerila Walker (Lepidoptera: Arctiidae). Syst. Entomol. 22(1):1-44, http://dx.doi.org/10.1046/j.1365-3113.1997. d01-21.x

HEPPNER, J.B. 1991. Faunal regions and the diversity of Lepidoptera. Trop. Lepid. 2(1):1-85.

HILT, N. \& FIEDLER, K. 2005. Diversity and composition of Arctiidae moth ensembles along a successional gradient in the Ecuadorian Andes. Divers. Distrib. 11(5):387-398, http://dx.doi.org/10.1111/j.1366-9516. 2005.00167.x

HILT, N. \& FIEDLER, K. 2006. Arctiid moth ensembles along a successional gradient in the Ecuadorian montane rain forest zone: how different are subfamilies and tribes? J. Biogeogr. 33(1): 108-120, http://dx.doi.org/10.1111/j.1365-2699.2005.01360.x

JEFFRIES, M.J. \& LAWTON, J.H. 1984. Enemy free space and the structure of ecological communities. Biol. J. Linn. Soc. 23:269-286, http://dx.doi.org/10.1111/j.1095-8312.1984.tb00145.x

KLINK, C.A. \& MACHADO, R.B. 2005. Conservation of the Brazilian Cerrado. Conserv. Biol. 19(3):707-713, http://dx.doi.org/ 10.1111/j.1523-1739.2005.00702.x
LEWINSOHN, T.M., FREITAS, A.V.L. \& PRADO, P.I. 2005. Conservation of terrestrial invertebrates and their habitats in Brazil. Conserv. Biol. 19:640-645, http://dx.doi.org/10.1111/j.15231739.2005.00682.x

MELO, A.S. 2004. A critique of the use of jackknife and related nonparametric techniques to estimate species richness. Community Ecol. 5(2):149-157, http://dx.doi.org/10.1556/ComEc.5.2004.2.1

MORAIS, H.C., DINIZ, I.R. \& SILVA, D.M.S. 1999. Caterpillar seasonality in a central Brazilian cerrado. Rev. Biol. Trop. 47(4): 1025-1033.

MORENO, C., CIANCIARUSO, M.V., SGARBI, L.F. \& FERRO, V.G. 2014. Richness and composition of tiger moths (Erebidae: Arctiinae) in a Neotropical savanna: are heterogeneous habitats richer in species? Nat. Conserv. 12(2):138-143, http://dx.doi.org/10.1016/j.ncon.2014.09.006

MUIRHEAD-THOMPSON, R.C. 1991. Trap responses of flying insects. Academic Press, London.

MYERS, N., MITTERMEIER, R.A., MITTERMEIER, C.G., FONSECA, G.A.B. \& KENT, J. 2000. Biodiversity hotspots for conservation priorities. Nature. 403(6772):853-858, http://dx.doi. org/10.1038/35002501

OLIVEIRA-FILHO, A.T. \& RATTER, J.A. 2002. Vegetation physiognomies and woody flora of the Cerrado biome. In The Cerrados of Brazil. Ecology and natural history of a Neotropical savanna (P.S. Oliveira \& R.J. Marquis, eds). Columbia University Press, New York, p. 91-120.

PIÑAS-RUBIO, F., \& MANZANO, P.I. 2003. Mariposas del Ecuador. Familia: Arctiidae. Subfamilia: Ctenuchinae. Compañía de Jesús, Quito.

PIÑAS-RUBIO, F., RAB-GREEN, S., ONORE, G. \& MANZANO, P.I. 2000. Mariposas del Ecuador. Familia: Arctiidae. Subfamilias: Arctiinae y Pericopinae. Pontificia Universidad Católica del Ecuador, Quito.

PINHEIRO, F., DINIZ, I.R., COELHO, D. \& BANDEIRA, M.P.S. 2002. Seasonal pattern of insect abundance in the Brazilian cerrado. Austral Ecol. 27:132-136, http://dx.doi.org/10.1046/j.1442-9993.2002. 01165. $\mathrm{x}$

RAMOS-NETO, M.B. \& PIVELLO, V.R. 2000. Lightning fires in a Brazilian savanna National Park: rethinking management strategies. Environ. Manage. 26(6):675-684, http://dx.doi.org/10.1007/s0026700 10124

RODRIGUES, F.H.G., SILVEIRA, L., JÁCOMO, A.T.A., CARMIGNOTTO, A.P., BEZERRA, A.M.R., COELHO, D.C., GARBOGINI, H., PAGNOZZI, J. \& HASS, A. 2002. Composition and characterization of the mammal fauna of Emas National Park, Goiás, Brasil. Rev. Bras. Zool. 19(2):589-600, http://dx.doi. org/10.1590/S0101-81752002000200015

RUGGIERO, P.G.C., BATALHA, M.A., PIVELlO, V.R. \& MEIRELLES, S.T. 2002. Soil-vegetation relationships in cerrado (Brazilian savanna) and semideciduous forest, Southeastern Brazil. Plant Ecol. 160(1):1-16, http://dx.doi.org/10.1023/A:1015819219386

SILVEIRA NETO, S. \& SILVEIRA, A. C. 1969. Armadilha luminosa modelo "Luiz de Queiroz". O Solo 61:19-21.

SINGER, M.S. \& BERNAYS, E.A. 2009. Specialized generalists: Behavioral and evolutionary ecology of polyphagous wooly bear caterpillars. In Tiger Moths and Wolly Bears, Behavior, Ecology and Evolution of the Arctiidae (W.E. Conner, ed.). Oxford University Press, New York, p. 103-114.

WATSON, A. \& GOODGER, D.T. 1986. Catalogue of the Neotropical tiger-moths. Occas. Pap. Syst. Entomol. 1(1):1-70.

WELlER, S., DACOSTA, M., SIMMONS, R., DITTMAR, K. \& WHITING, M. 2009. Evolution and taxonomic confusion in Arctiidae. In Tiger Moths and Wolly Bears, Behavior, Ecology and Evolution of the Arctiidae (W.E. Conner, ed.). Oxford University Press, New York, p. 11-30. 
YELA, J.L. \& HOLYOAK, M. 1997. Effects of moonlight and meterological factors on light bait trap catches of Noctuid moths (Lepidoptera: Noctuidae). Environ. Entomol. 26(6):1283-1290, http://dx.doi.org/10.1093/ee/26.6.1283
ZAHIRI, R., HOLLOWAY, J.D., KITCHING, I.J., LAFONTAINE, J.D., MUTANEN, M. \& WAHLBERG, N. 2012. Molecular phylogenetics of Erebidae (Lepidoptera, Noctuoidea). Syst. Entomol. 37(1):102-124, http://dx.doi.org/10.1111/j.1365-3113.2011.00607.x

Received: 09/04/2015

Revised: 23/02/2016

Accepted: 16/05/2016 